\title{
CULTURAL VALUES OF THE SITES RECORDED AS A SIGNIFICANT GEOHERITAGE IN NORTH MACEDONIA
}

DOI: http://dx.doi.org/10.18509/GBP.2019.03

UDC: 911.5:551.43/.44.03(497.7)

\author{
Anita Todorova \\ Dragan Kolchakovski \\ University of „Ss Cyril and Methodius”-Skopje, Faculty of natural sciences and mathematics, \\ Institute of geography, Skopje, North Macedonia
}

\begin{abstract}
In this paper, the cultural values are processed regardless of the period when they were created, but they are recognizable and recorded, which are located on the geosites that are part of the geoheritage. The cultural values are processed in a recognizable denudation relief in the geoheritage, then some elements of the cultural heritage are on the cliffs themselves as the appearance of the geoheritage caused by an abrasive process. From the fluvial geoheritage are considered buildings that have cultural and historical significance such as "bridges", and are located in the famous gorges as part of the geoheritage. Special attention is paid to fresco painting and other buildings that are located in the inner, most initial part in caves. The main task and further goal should be the accurate identification and classification of the cultural heritage located on the geosites themselves, which should also be part of the geoheritage. After their identification and classification, it is necessary to implement their preservation or protection.
\end{abstract}

Keywords: cultural values, geoheritage, conservation, North Macedonia

\section{INTRODUCTION}

The formation of the relief forms on the Earth's surface involved a variety of external (exogenous) and internal (endogenous) processes that contributed the shape of the relief forms in their variety or diversity. This variety is part of the overall geodiversity. Geodiversity is a diversity of inanimate nature. Geodiversity can be defined simply as „the natural range (diversity) of geological (rocks, minerals, fossils), geomorphological (land form, physical processes) and soil features. It includes their assemblages, relationships, properties, interpretations and systems" [6]. According to Serrano and Ruiz-Flano [21], the variability of abiotic nature, including lithological, tectonic, geomorphological, soil, hydrological, topographical elements and physical processes on the land surface and in the seas and oceans, together with systems generated by natural, endogenous and exogenous human processes, which cover the diversity of particles, elements and sites. Geodiversity needs to be properly managed, and it should also be protected for two different reasons. First, because of his values, and secondly because of his human influences [6]. In the period of XX and XXI century certain authors tried to determine the values of natural resources. Wilson [25] distinguishes two basic types of values of natural resources: economic value (exploitation of resources) and cultural values (protection of aesthetic and educational resources). Further on, the authors Bennett and Doyle [1], [4] gave a more extensive classification of the values of geodiversity and distinguished them into four categories: intrinsic value, cultural and aesthetic value, economic value and research and educational value. The author Grey [6] joined them in 
these researches, where he gives a more detailed analysis of the values of geodiversity and gives his own classification where he emphasizes the following values: intrinsic or existence value, cultural, aesthetic, economic, functional and research and educational value. In 2005, Reynard [20] also analyzed the values and emphasized two values: scientific value and additional values that include cultural, economic, aesthetic and ecological value.

The cultural value of geodiversity is the value of the physical environment that is determined by man because of its importance to society and the community. The cultural value is classified in several ways: geomythology or folklore, archaeological and historical, spiritual values and sense of place [6]. While, Reynard [20] the cultural values of the geoheritage sites, explains them in sub-groups as follows: religious, historical, artistic and literature and geohistorical importance. In the past, very often the formation of a rock or some relief forms was related to the beliefs of supernatural forces and added great importance to these formations and were associated with some legends. Different geological and geomorphological forms served as a home or shelter for man, and various types of rocks served as tools and weapons. For these reasons, these forms are of great historical significance and are of great benefit to archeology. In the past, many forms and rock formations have been used for religious and spiritual rituals, and as a result, geodiversity can have a religious or spiritual value. In many places local people feel connected with their physical environment and thus develop a sense of place or environment. From certain relief forms or rock formations, people can use them for orientation in the space and to see the differences in height. Some geomorphological forms are sung in poems, mentioned in books, or shown in pictures.

The occurrences and shapes separated from geodiversity that are of great importance for mankind create the geoheritage. As geoheritage sites can be the following: minerals, rocks, ores, fossils, layers of fossils, geological profiles, soil profiles (especially relict, non-type or soils with fossil character), various geomorphological forms, including underground (caves, cave decorations), specific sources, mineral and thermo-mineral springs, swamps and lake basins (tectonic, glacial), etc. [10]. Geoheritage includes those elements of natural geodiversity which are of great value to humans for non-depleting purposes which do not reduce their intrinsic or ecological values [22]. The geoheritage sites that are distinguished by their representativeness, authenticity, typology and diversity have certain values. It is not difficult to find examples in the geoheritage sites where they display their cultural values.

This paper presents several localities that are registered as significant geoheritage in North Macedonia. Several examples have been given that arise from a different type of relief, which have significant cultural values important for mankind. 


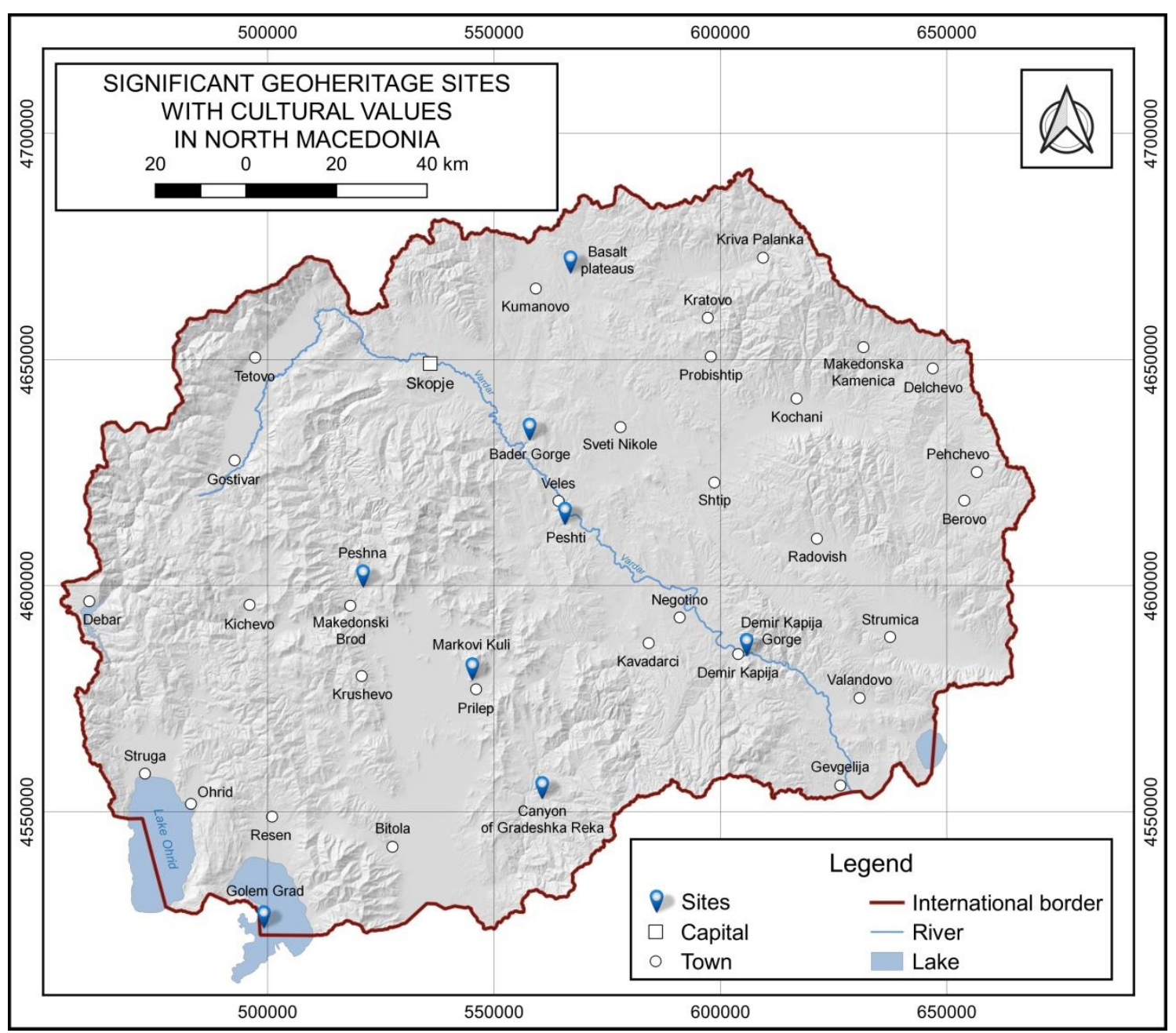

Figure 1. Location on the significant geoheritage sites with cultural values

\section{PURPOSE OF THE STUDY}

Although the North Macedonia occupies a relatively small area of $25713 \mathrm{~km}^{2}$, it possesses numerous geological, geomorphological and hydrological relief forms. They differ because of their diversity and uniqueness. Some of them are significant because they were used by a person who gives them special meaning. The purpose of this paper is to present certain relief forms and rock formations used by a man who served as a dwelling place or as a sanctuary, part of the rocks that were used as tools or weapons, and he associated certain phenomena and forms with certain legends. Cultural values are processed in recognizable and protected denudation relief forms. An example of the natural monument „Markovi Kuli” and the archaeological findings discovered are of great cultural significance. Certain gorges (Baderska Gorge and Demir Kapija Gorge) and canyons (the canyon of Gradeshka Reka) are distinguished from the fluvial relief forms, which have built on them buildings of cultural and historical significance. From the abrasive relief form, the island Golem Grad on the Lake Prespa has been analyzed, where it has been used as a dwelling and sanctuary of mankind since many years ago, and as an evidence of that there are remains of several churches. Particular attention is paid to the fresco painting and other buildings that are found in the innermost part of the initial part of the caves. Some of the described caves are located in the gorge Peshti and the cave Peshna. The cultural values apart from being analyzed in various recent relief forms were 
also analyzed in palaeorelief forms, and in palaeovolcanic forms. This paper will also include the description of the archaeological finds that are located at the Basaltic plateaus near the village of Mlado Nagorichane.

\section{GEOHERITAGE SITES WITH CULTURAL VALUES}

In this paper, eleven geoheritage sites will be presented, which differ in their origin, i.e. they differ according to the type of relief and the characteristics that play a major role for the cultural and spiritual values of the human community.

\section{The monument of nature „Markovi Kuli”}

The monument of nature „Markovi Kuli" or the granodiorite complex is located in the central part of North Macedonia along the northeast edge of the Pelagonia Valley, north of the city of Prilep. Space has consisted of more imposing hills connected in two parallel arrays with a stretch of north-northwest-south-southeast. According to geochronological research, the granodiorites in the vicinity of Prilep are considered to have Hercynian age, or more precisely about 300 million years [11]. The denudation relief forms represented at this site have been mentioned since 1926 in the literature by J. Cvijic [3], but V.S. Radovanovic [19] detailed in his capital work the way of their occurrence in the granodiorite rocks. These rocks were influenced by processes of physical fragmentation and chemical decomposition, which is the most important process for creating the denudation relief forms of the site. The denudation relief forms can be divided according to the origin, the form or the appearance they have (morphographically) and according to the dimensions of the occurrence (morphometric). The micro-relief form of the locality „Markovi Kuli" can be divided into three main groups: a group of small rocky blocks, shapes on rock pillars and blocks and depression in gneiss rocks [19]. The most interesting and striking is the elephant-shaped rock formation at the foot of Markovi Kuli (945 m). In North Macedonia, in the category of the monument of nature, the site was first declared in 1967 and re-declared in 2006. Due to the outstanding natural values and fulfilling part of the conditions and criteria on June 24, 2004, the monument of nature Markovi Kuli is inscribed on the tentative list of UNESCO.

The configuration of the terrain and the favorable geographical position contributed to this area being inhabited long ago. The area around the natural monument was inhabited since the late Eneolithic where an eneolithic settlement was built which was located on the hill of Markovi Kuli. As evidence of this is the remains of residential buildings and the findings of garden ceramics. The remains of a necropolis and a settlement dating back to the early Bronze Age are recorded on the southern slopes of the formation of Markovi Kuli. In this period at the site Svetec near Varosh, a finding of a grave in a cave was discovered. Also, settlement remains and a necropolis from the Iron Age was discovered in the southern part of Markovi Kuli. From the classical period (IV century BC), remains of a necropolis in the western part of Varosh, in the locality of Zagrad were also discovered. In the period of the Hellenistic time, remains of settlements were discovered on the hills Treskavets, Baba and Markovi Kuli. Segments of the settlement (assumed Ceramiae) were discovered in the southern, western and southeastern parts of the hill Markovi Kuli. Apart from settlements in this period, a great number of tombs in rocks dating from the II and I century BC are of great importance. Remains of buildings, coins, ceramics, tools, stone plastics and others dating back to early Roman period were discovered on the hills of Markovi Kuli, Treskavets and Kukul. In the period from the end of the III century and the late V century or late Roman period, ancient settlements 
were built on the hills Treskavets (Kolobaisa), Markovi Kuli (Ceramiae) and Kukul (the presumed Babas). Archaeological remains were also discovered from the Early Byzantine period. In the early Middle Ages, remains of the hills of Kukul and Treskavec were discovered. In the Middle Ages in the eastern, southern and western parts of the hill Markovi Kuli, remains of a pro-urban settlement were found [14]. The fortress „Markovi Kuli" Varosh, built from the XIII-XIV centuries, is also of great importance. The walls of the fortress are with a thickness of $1 \mathrm{~m}-1 \mathrm{~m} 30 \mathrm{~cm}$. There are three wall belts on the fort. The first belt is the acropolis located on the highest northeastern part of the Chardak hill. The second belt is a neighborhood part mingled in the saddle south of the acropolis. On the north wall there is a dual port and a large guardhouse between the entrances. On the southern city wall there are 3 well preserved towers. The third belt consists of a series of short walls. It served as a temporary getaway in the late XIV century. After the death of King Marko (1395), the settlement of Markovi Kuli was omitted because the fort was captured by the Turkish guard [16]. In this period of great significance are the sacral objects, the churches of St. Nikola, St. Dimitrija and St. Archangel Michael. Of great importance is the establishment of the late medieval city of Prilep, which represented one of the important military, political, cultural and economic centers on the Balkan Peninsula. A widespread acropolis is found on the upper parts of the hill (walls, towers, entrances etc.) and open suburb - Varosh, which is spread in the lower slopes of Markovi Kuli (panagishte, churches, representative buildings, etc.). On the hill Treskavec there is also a monastery with a church dedicated to the Assumption of the Holy Mother of God [14]. With decomposition on the granodiorite rocks on the horizontal surface are formed recessed relief forms. The people that relief forms called "footprints". According to local talking these footprints were of King Marko.

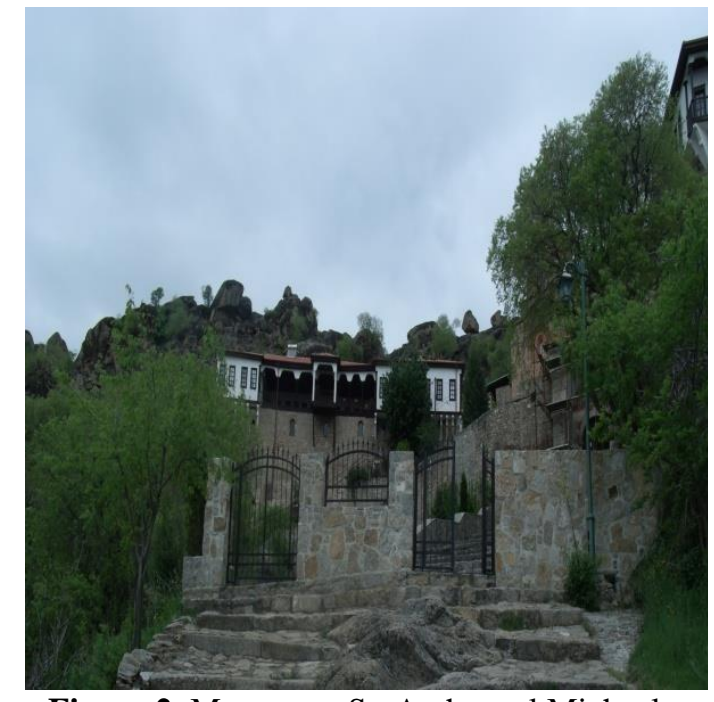

Figure 2. Monastery St. Archangel Michael

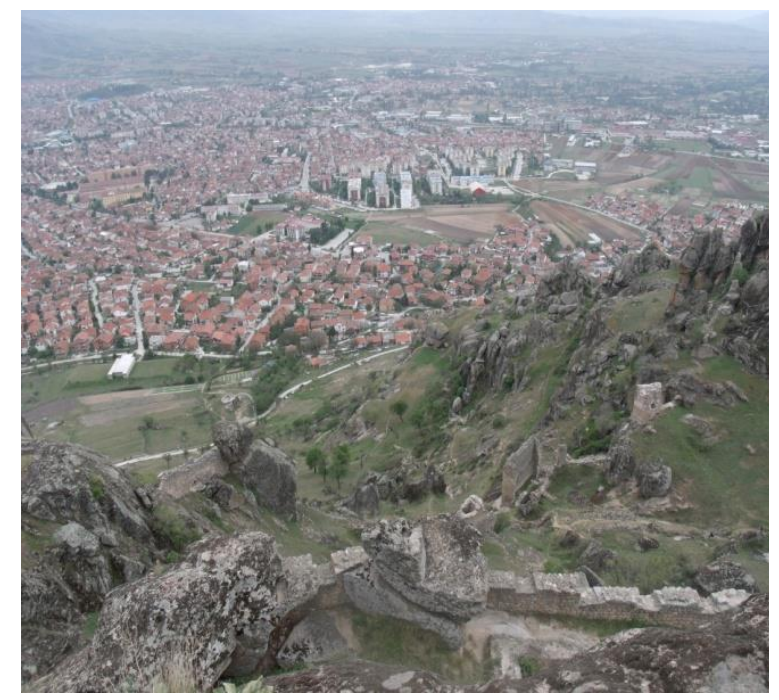

Figure 3. The medieval towers on the MN „Markovi Kuli”

(Photo: Todorova)

\section{The Bader gorge}

This gorge (Prnarska Klisura on the hill Prnar $489 \mathrm{~m}$ ) is an epigenetic gorge in the lower course of the Pcinja River. The gorge extends between the village of Bader in the Skopje Valley until the inflow of Pchinja into the river Vardar in a total length of $9.5 \mathrm{~km}$. The gorge is graven into Paleozoic formations between the hills of Kamenica $(479 \mathrm{~m})$ and Shtur $(508 \mathrm{~m})$ to the east, Mramor (418 m) and Prnar (489 m) to the west. The total 
height of the vertical sides is $385 \mathrm{~m}$. This site belongs to the protected area „Katlanovo landscape" and is protected in the category of a monument of nature. At the gorge itself there is a medieval building from the XII to the XIV century, i.e. the archaeological site „Markovi Kuli” (the city „Kozle” or the Castle near Pcinja). The earliest findings for the castle date from the late Roman period and from the Iron Age where graves were discovered. On this position in the late antique period a border castle was built that served to control the two routes on the main road. Across through this hardly passable position a borderline was made between the provinces of Macedonia and Dardania (Upper Mezia), and the fortress oversaw the border crossings. In the Middle Ages a completely new fortress was built. The fortress had an oval shape with its entrance on the eastern side where a massive tower was built. Inside the fortress was the house of the master of the fortress. On the slope itself, north and east of the castle were the economic part where the towers were located. The city of Kozle is mentioned in the Serbian church chapters from the time of Stefan Dusan. The city was governed by kefaliah, which means it was a royal (state) fortress. The fortress controlled the Vardar road between Skopje and Velesko Pole. At that time Kozle was a Serbian border guard [16]



Figure 4. The Castle on the river Pcinja (Photo: Todorova)

\section{The Demir Kapija gorge}

The Demir Kapija gorge is the fourth in a row of gorges on the river Vardar. It has a length of $19.5 \mathrm{~km}$, starts from the river mouth of the river Boshava to the village of Udovo. On the eastern side it is enclosed in the branches of Serta (Konechka Mountain) and Gradeshka Mountain, and on the west side with the hill Krastovec and Kozuf Mountain. The name derives from the Turkish words "demir" which means iron and "gate" meaning the door or port, and hence the name "Iron Gate". With the outflow of the middle Vardar Lake toward the end of the Pliocene the river Vardar began with the creation of the Demir Kapija valley, gradually seizing the complex Jurassic limestone. At the beginning of the Demir Kapija valley a canyon is formed where the sides of the valley are almost vertical and fall at an angle of $70-90^{\circ}$. The length of the canyon section is $900 \mathrm{~m}$. The highest peaks reach a height of $355 \mathrm{~m}$ on the left side up to $230 \mathrm{~m}$ on the right side. It is one of the richest ornithological reserves in Europe according to the presence of rare birds of prey. It is protected by law in the category of monuments of nature. 
The Demir Kapija gorge had a strategic position and represented a port that prevented the penetration of various armies from north to south or vice versa. During the First World War, Demir Kapija gained a significant role for the warring Central Forces and the Entente. In order to improve the military transport of food and weapons, German soldiers broke a tunnel at the entrance to the gorge on the right coast of the river Vardar. In front of the tunnel on the underside of the rock in carved out letters stands the inscription in German and the words "WILHELM II DEUTSCHER KAISER KONIG VON PREUSSEN BEFAHL SEINEN SOLDATEN DIESE STRASSE ZU BAUEN 1916" which means "WILHELM II GERMAN IMPERATRIC KING OF PRUSSIA ORDERED TO HIS SOLDIERS TO BUILD THIS ROAD 1916".

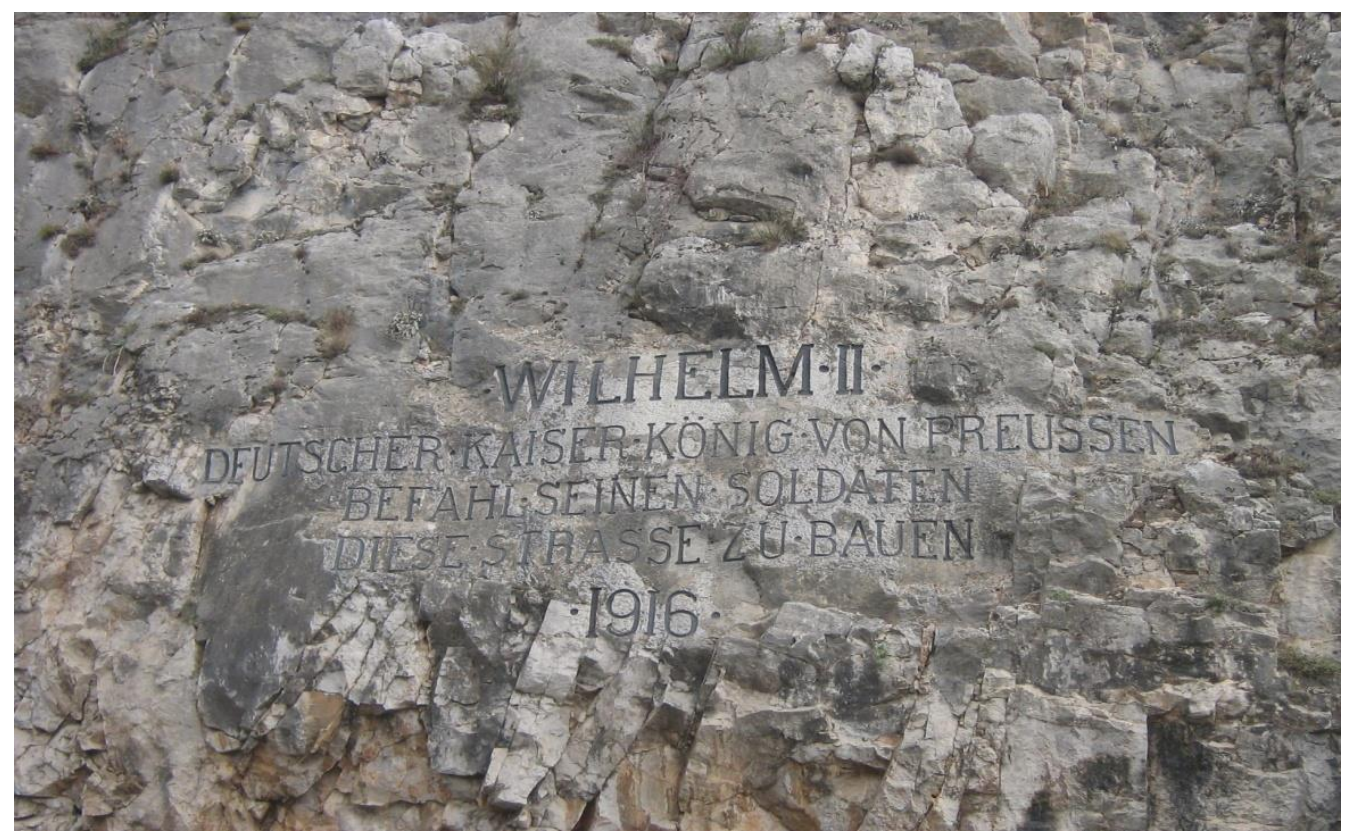

Figure 5. Inscription with carved out letters in the Demir Kapija gorge (photo: Todorova)

\section{The canyon of the river Gradeshka}

The canyon of the river Gradeshka is located in the Mariovo region, northeast of the city of Bitola. The river Gradeshka flows from the Kozjak mountain at an altitude of $1600 \mathrm{~m}$ above sea level. It inflows into the river Crna under Chebren. It is $26 \mathrm{~km}$ long. The river Gradeshka has a canyon valley from Staravina and all the way to the inflow into the river Crna. The canyon is incorporated into Precambrian gneiss rocks between the hills of the Chukite $(640 \mathrm{~m})$ to the north and Vrvot $(726 \mathrm{~m})$ to the south. The canyon of this river is protected by law in the category of a monument of nature. Apart from the fact that the canyon has a landscape value, also of special cultural significance is the bridge of the river Gradeshka. Due to the vicinity of the village Zovik this bridge is called „The bridge near the village Zovik". The purpose of the bridge was bridging the Gradeska River. The bridge was built for communication of the population with the inhabited territories on the other side of the river, that is, with the Mariovo villages Beshishte and Polchishte. In the medieval period, the bridge was wooden, but due to overburden the bridge collapsed in 1950. In the period from 1954/55 the bridge was rebuilt by the local population, but now the bridge was built of stone blocks and represents a stone bridge. It is 15 meters high [8]. In the immediate vicinity of the bridge on a high rock the portrait of St Georgi was 
painted. The bridge, because it was used in the scene from the movie "Dust" by director Milco Mancevski is also called "Movie Bridge".

\section{The island of Golem Grad}

The island of Golem Grad is located between the triangle of North Macedonia, Albania and Greece. For the island of Golem Grad there are typical cliffs that actually circumvent its coast. It is surrounded by steep cliffs on all sides that reach a height of up to $10 \mathrm{~m}$ which contribute to being unapproachable, but the access to the island is only from the northwest side. The island is composed of Triassic limestone, it has a rhomboid form and covers an area of $0.275 \mathrm{~km}^{2}$ [23]. On the island there are two heights on the northeast and south. The highest point on the island is $901 \mathrm{~m} \mathrm{[23].} \mathrm{The} \mathrm{island} \mathrm{is} \mathrm{densely} \mathrm{forested} \mathrm{with}$ pine (Pinus peuce) and is known as the Snake Island, as there are various types of snakes. It was declared a Strict Nature Reserve and belongs to the National Park Galicica. The island is an ancient settlement and a medieval monastery complex. Archaeological research on the island has been carried out since 1967. Archaeologists discovered a settlement from the ancient period that belonged to Orestida in Upper Macedonia. The settlement is confirmed by the discovery of residential buildings from the Hellenistic and Roman periods. Three sacred basilicas from the V and VI century and four churches from the XIII and XIV centuries have been explored from the sacral objects. The best preserved is the church of St. Peter, painted in the XIV century [5].

\section{The caves in the Peshti gorge}

The Peshti gorge is located in the central part of North Macedonia, south of the city of Veles. It lies near the river mouth of Babuna into the Vardar. The Peshti gorge got its name from the fact that there are many caves distributed on both sides of the gorge, which represent more characteristic and almost unique rocky underground forms in this area. The river Babuna with mild meandering through the field of Makarovec penetrates into its inflow to the Vardar. The river's water deeply cuts the thick layers of Mesozoic limestones with cretaceous old age where the gorge was formed. The cuttings took place gradually, depending on the lowering of the level of the river Vardar. The Peshti gorge is about $500 \mathrm{~m}$ long [13]. From the underground karst relief forms in these areas there are mostly caves. Many caves are explored, some of which have no names and are marked with numbers. Some of the explored caves are also interesting for archaeologists because apart from the cave decorations, canals and halls in the caves there are also remnants of medieval churches, frescoes and artifacts from a prehistoric man. At about $90 \mathrm{~m}$ above the river bed of Babuna near the entrance to the gorge there is a smaller cave called "Crkviche". The total explored length is $21 \mathrm{~m}$. The channel of this cave is composed of three plunge pools. In the entrance part of the cave there are remains of frescoes that prove that once this cave was a shelter for the monks and was used as a prayer place. The cave is built with an underground independent stream that flows underground into Babuna [15]. The cave Markova Crkva is located at a height of $85 \mathrm{~m}$ above the Babuna riverbed. This cave has two openings, of which the lower one is accessible. The remains of the church's walls suggest that at the very entrance of the cave the church of St Nikola was built from the middle ages according to S. Simic through Mankovic, [15]. The cave got its name exactly because of the church. The total researched length of the cave is $69 \mathrm{~m}$. To the left of the entrance there is a terrace that was a remnant of the former watercourse that siphoned through the upper opening. Later on, the underground flow dropped down and broke through the lower opening by adjusting its profile to Babuna. His bottom is 
covered with clay [15]. On the right side of the gorge there is the entrance of the cave Monashka. It was named after the remains of frescoes found in it and this cave was used as a prayer place. It is a small cave built in the vertical layers of the Peshti gorge. Under the entrance of the cave there is a part $1.5 \mathrm{~m}$ deep, built from the flow of water that descends from the canal [15]. The cave Makarovec is located on the right valley side of the river Babuna. It was built from a variety of channels. The opening and entrance of the cave are at a height of $110 \mathrm{~m}$ above the bed of Babuna at an altitude of $300 \mathrm{~m}$. The entrance of the cave has a kidney shape, $8.70 \mathrm{~m}$ wide and $6 \mathrm{~m}$ high. During paleontological exploration in the cave, artifacts of the prehistoric man were discovered (artifacts resemble buttons, scraper and various blades) [15]. The Peshti gorge is proposed to be protected in the category of Strict Nature Reserve, and the cave Makarovec is proposed to be protected in the category of a monument of nature. The remaining three caves need to carry out further research and to be proposed to be protected.

\section{The cave Peshna}

Cave Peshna is located on the right valley side of the river Treska, in the Porece basin near Makedonski Brod. The cave represents one of the most attractive natural beauties in North Macedonia. Characteristic of this cave is its entrance with impressive dimensions $(52.4 \times 16.8 \mathrm{~m})$ and it has a small length of only $50 \mathrm{~m}$ [12]. From the far northern part of the cave, strong spring breaks out after heavy rains and melting of the snow, which completely dries out during the dry periods of the year. The Peshna cave is proposed to be protected by law in the category of the natural monument. At the entrance of the cave there is a medieval fortress. The remains of the fortress in the cave are related to the area "Devini Towers". According to local legends two sisters of King Marko lived in the two fortresses. He had four sisters, Deva, Peshta, Kita and Dzvezda. Deva lived in the village of Devich, and Peshta lived in the cave and because of her the cave got its name [7].

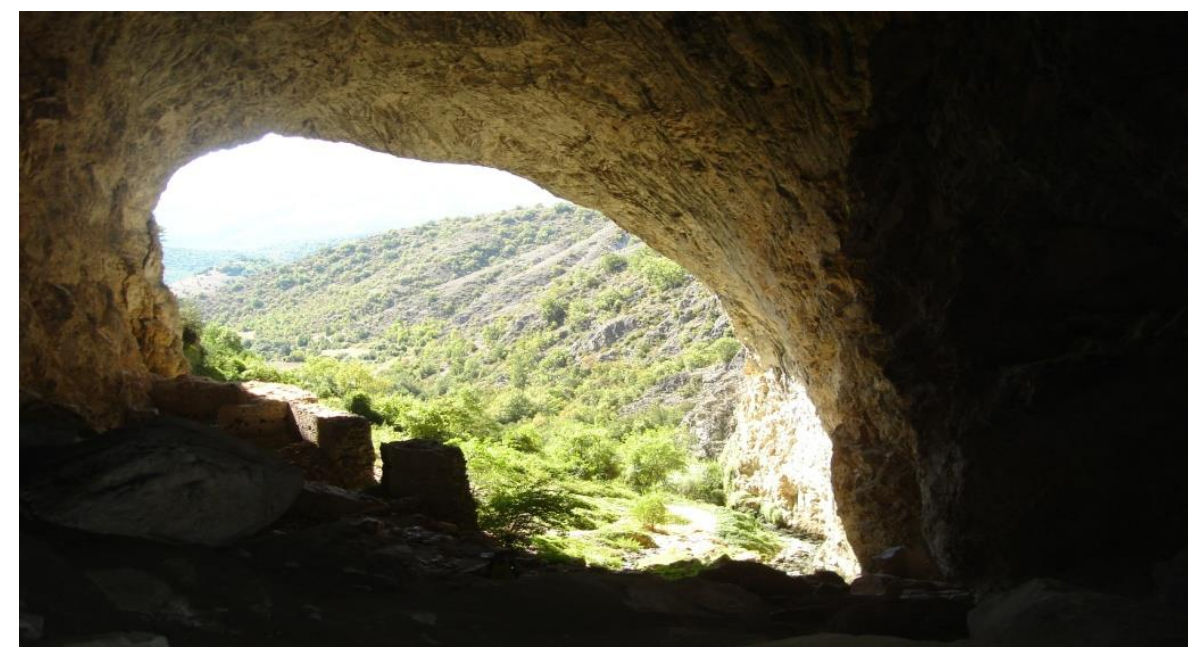

Figure 6. The medieval towers in the cave Peshna (photo: Todorova)

\section{The site Basalt plateaus}

Apart from the presence of various recent relief forms, the Palaeorelief forms are of significant importance. In this type of relief there are relief forms whose processes that have contributed to their creation have ended long since or are no longer functioning. During the Cenozoic era, more precisely in the tertiary and lower quaternary, an intense volcanic activity with a large amount of pyroclastic material and various volcanic rocks 
[24] was taking place on the territory of North Macedonia, but these volcanic processes are no longer active in the territory of North Macedonia and as a result, the Palaeovolcanic relief forms are highlighted. As a typical phenomenon of this type of relief forms is the Basalt plateaus site. It is located in the northeastern part of North Macedonia, near the village of Mlado Nagorichane. This site belongs to the Kumanovo-Sveti Nikole volcanic area. The volcanic activity in this area was followed by the peaceful pouring of basic lava, and as a result, the lava consolidated on the surface itself and formed a plateau.

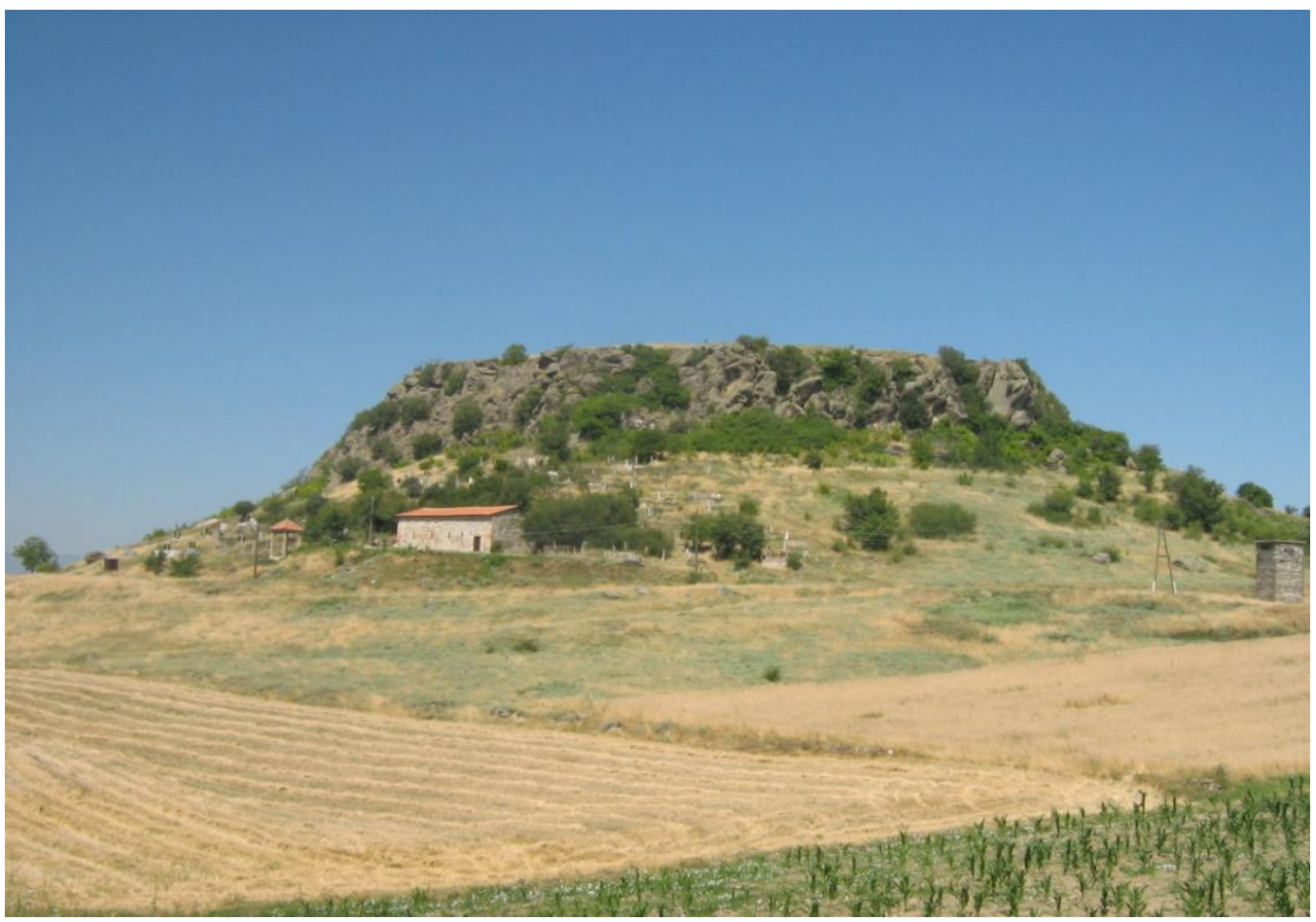

Figure 7. Kostoperska Karpa with the church of St. Petka (photo: Todorova)

Neotectonic processes and erosion contributed to dividing the plateau into several parts. In this space, the plateau itself was divided into eight smaller plateaus reaching a height of 50-80 meters which had a meridian stretching path [9]. The plateaus are composed of chunky blackish basalt, and in some of them there are red layers of a very light sponge mass of lava. The largest of these basalt plateaus is the plateau called Tsabernik, the smaller of which is the Sreden Kamen, and the smallest one is the basalt plateau called Ostrovitsa [2]. This site is proposed to be protected by law in the category of a monument of nature. The most prominent basalt plateaus are the „Kostoperska Karpa” and „Vujovska Karpa” which are located directly to the Kumanovo-Kriva Palanka highway. These plateaus were also interesting for archaeologists. They were explored by a group of archaeologists and they discovered various artifacts that confirmed that at some point in time there was life on these plateaus. Some of the basalt plateaus have a name given to them by the local population and it is assumed that once there was life on those plateaus and they also have their own stories or legends. One of them is the „Kostoperska Karpa” or „Zhegligovski Kamen”.

In 1983, 1988 and 2000, archaeological researches were carried out. In the protective excavations six grave parts of the IV century were discovered and explored. The results of the overall work showed that it is a large settlement with a wide chronological and cultural continuity. The longest settlement is present on the highest part of the rock 
acropolis, that is, the plateau which was in some way naturally protected. On the Zhegligovski Kamen, or more commonly known as the Kostoperska Karpa, there was a settlement from the Copper Age (Eneolithc), located on the plateau of the rock. Fragments of ceramic pots from the iron age were discovered on the southern terrace. Additional parts were discovered in the central part of the acropolis which suggested that once there was a basilica on that location. On the southwestern gate there were remnants of a water tank coated with hydrostatic mortar. The cultural chronology of the settlement ended in the Turkish period, and as witnesses of this were the fragments of yellow and green stained ceramics [17].

Medieval churches were built near the plateau. One of these churches is the church of St. Petka dating from the XIII-XIV century, but today half of it is destroyed. In the slopes of the plateau on an area of 2-3 ha traces of unscratched underbuilts were found (varosh) dating from late medieval ceramics, Turkish akchas, etc. [16].

Further on, the church of St. George (1406/7, without frescoes), the church of St. Nikola, the church of St. Vrachi, the church of St. Archangel and the church of the Holy Mother of God (in ruins) [16].

\section{DISCUSSION AND CONCLUSION}

All presented geoheritage sites are characterized by significant cultural values, which are especially important for archeology, history, geomythology and religion. They represent a strong link between geoheritage and cultural heritage.

The monument of nature „Markovi Kuli” due to the good location, that is, the strategic position, throughout the history of this site, has left marks that testify that this space was inhabited since the Eneolithic. Those remains are of great importance for archeology. As more significant cultural values, we can single out the medieval towers, the church of Sts. Archangel Michael and the Treskavec monastery or Holy mother of God. Interesting is the relief forms in shapes like footprints, and that is related to the legend of King Marco. All these archaeological findings are of great importance for the cultural heritage of North Macedonia. Of great cultural and historical significance is the Castle of the river Pchinja, located on the Bader gorge. He served as a border crossing between the provinces of Macedonia and Dardania, and later controlled the Vardar road between Skopje and Velesko Pole. On the right coast of the river Vardar in the Demir Kapija gorge there is a rock with carved out letters of the time from the First World War which are of great historical significance. The stone bridge and the landscape of the canyon of the river Gradeshka possess great cultural values. The stone bridge is very important for archeology and has historical significance. With the showing the stone bridge in the movie „Dust”, he leaves a permanent mark on the cultural heritage in North Macedonia. From the religious values, most characteristic is the fresco of Sts. George painted on a rock. The remains of settlements and sacred objects on the island of Golem Grad are of great importance for archeology and possess religious values. In the caves of the Peshti gorge, frescoes and remains of a church have been found which prove that these caves had long been used as a shelter for the monks to carry out their church duties. It contributes to these caves to have religious and spiritual values. In the cave Makarovec there are artifacts from a prehistoric human that are of great importance for archeology. Also of great significance for archeology are the medieval towers in the cave Peshna which are also shown through some legends that are important for geomythology. The discovered artifacts at the Basalt plateaus site confirm that there was life since the Eneolithic period which is still very important for archaeological data. The medieval 
churches that are located on and around the Kostoperska Karpa have significant religious value.

As the main task and further goal it is necessary to give the correct identification and classification of the cultural heritage located on the geoheritage sites. It is necessary to classify the cultural heritage according to certain cultural values, i.e. geomythology, archeology, history, religious and spiritual values in protected and recorded geoheritage sites. Because of the people's visit to the geoheritage sites to see the remains of some buildings, churches and remains of frescoes that are important for archaeological and historical significance and to enjoy the landscape value, they directly endanger them. For this reason it is necessary to appropriately protect them. After their identification and classification it is necessary to conduct their conservation and protection. Conservation refers to the protection and management of natural and cultural values. Under the influence of various natural and anthropogenic processes, the geoheritage sites can be subjected to degradation and even complete destruction [10]. Geoconservation includes protection, physical management and improvement of geo-regions of international and national importance for the purpose of scientific and educational exploitation [18]. The geoheritage sites and cultural heritage can be protected at the very spot of creation in-situ, but the found artifacts should be protected in museum collections. North Macedonia has rich geological, geomorphological and hydrological diversity and rich cultural heritage and therefore has significant geo-tourist potential. The geoheritage sites are examples of exceptional geological, geomorphological, pedological and archaeological significance, which in recent years have been used as a tool for developing geo-tourist destinations. The connection of geotourism to cultural tourism can be represented through the exploitation of geological resources, that is through some kind of art or cultural significance of the rocks and relief forms. The anthropological and paleontological resources can be included in the various geotourism offers.

\section{REFERENCES}

[1] Bennett, M.R. \& Doyle. P. Environmental Geology, Wiley, Chichester, 1997.

[2] Cvijich J. Geography and geology basics of Macedonia and Old Serbia, Belgrade, book 1, pp 1-688, 1906.

[3] Cvijich J. Geomorphology, second book, Beograd, pp. 193-588, 1926.

[4] Doyle, P. \& Bennett, M.R. Earth heritage conservation: past, present and future agendas. In Bennett, M.R. \& Doyle, P. (eds) Issues in Environmental Geology: A British Perspective. Geological Society, London, pp 41-67, 1998.

[5] Encyclopaedia Macedonica, A-L, Macedonian academy of sciences and arts, Lexicographical centre, Skopje, pp 372, 2009.

[6] Gray M. Geodiversity, Valuing and Conserving Abiotic Nature, Chichester, John Wiley \& Sons, U.K. pp 1-434, 2004.

[7]https://www.mbrod.gov.mk/index.php/mk/mestopolozhba/68-blog/informacii/126-pesna (visited 30.01.2019)

[8] http://www.novaci.mk/index.php/mk/kultura/predanija/47-mostot-vo-zovik

(visited 30.01.2019 година)

[9] Klincharov S. \& Anastasovski V. Geological and geomorphologic heritage of the Republic of Macedonia, Jurnal of the Serbian Institute for protecting nature, $n^{\circ} 48-49$, Belgrade, pp 91-97, 1998. 
[10] Kolchakovski D. \& Bogdanova B. Geodiversity in the Republic of Macedonia and its significance (identification, classification and protection), Proceedings of the Second Congress of Geographers from the Republic of Macedonia, Ohrid, pp 64-68, 2000.

[11] Kolchakovski D. Contribution to a research of micro-relief forms of the granodiorite rocks on the locality „Markovi Kuli”, Bulletin of Physical Geography, n² 2, Skopje, pp 5-23, 2005.

[12] Kolchakovski D. Geomorphology, Skopje, pp 367, 2006.

[13] Kostovski J.V. Peshti Gorge, Bulletin of the Serbian Geographical Society, Belgrade, vol. XXXIV, $\mathrm{n}^{\circ} 1, \mathrm{pp} .45-48,1956$.

[14] Management Plan-Draft Version, Monument of Nature „Markovi Kuli”- Prilep, Institute for Research of Old Slavic Culture - Prilep subject for management of the Monument of Nature „Markovi Kuli”, pp 1-155, 2018.

[15] Manakovich D. Some relief forms in the valley of the river Babuna and Topolka with the Titoveleshka Valley, Yr. Proceedings of PMF, Skopje, ${ }^{\circ}{ }^{\circ}$ 15, pp 87-139,1966.

[16] Mikulchic I. Medieval towns and fortresses in Macedonia, Macedonian Academy of Sciences and Arts, Skopje, pp 227-229, 249-254, 290-293, 1996.

[17] Nikolovski Z, Attachment to the late antique fortifications in the northeastern Macedonia (part of the doctoral dissertation "Antiquity of the northeastern part of the Republic of Macedonia"), Kumanovo

[18] ProGEO. Conservation our shared geo-heritage-a protocol on geoconservation principles, sustainable site use, management, fieldwork, fossil and mineral collecting, Sweden, pp 1-10, 2011.

[19] Radovanovich V.S. Small denudacial forms in gneiss land in South Serbia, Herald Skopje Science Society, book IV, Skopje, pp 53-120, 1928.

[20] Reynard, E. Gèomorphosites et paysages.- In: Gèomorphologie. Relief, processus, environnement $\mathrm{n}^{\circ}$ 3: 181-188, 2005.

[21] Serrano C.E. \& Ruiz-Flano P. Geodiversity. A theoretical and applied concept. Geographica Helvetica, Jb 62, Helt 3, pp 140-147, 2007.

[22] Sharples C. Concepts and principles of geoconservation, Tasmanian parks \& Wildlife service, Version 3, pp 1-79, 2002.

[23] Stojadinovich Ch. Geomorphological features on the Island Golem Grad in Prespa Lake, Geographical Reviews, n 6, Skopje, pp 117-121, 1968.

[24] Stojanovich M. Areas of extinct volcanoes on the territory of SR Macedonia, Annual proceedings of the Institute of Geography, Skopje, n 30, pp 149-166, 1986.

[25] Wilson, C. Earth Heritage Conservation. Geological Society London \& Open University, Milton Keynes, 1994. 